anerkjennelse innebærer, og hvordan det kan knyttes til velferdsstatens profesjoner og profesjonsutøvelse.

Boken har fire hovedkapitler foruten innledning og avslutning. I disse knyttes anerkjennelse suksessivt til identitet, omfordeling, profesjonsetikk og frimodighet. Det meste knyttes til en debatt om innholdet $i$ begrepet anerkjennelse, der den tyske sosialfilosofen Axel Honneth (f. 1949) og den amerikanske, politiske filosofen Nancy Fraser (f. 1947) er de sentrale bidragsyterne. Anerkjennelse som fenomen beskrives på individuelt og overordnet politisk nivå, og profesjonsutøvernes vanskelige rolle i midten kommer frem.

I innledningen definerer forfatterne begrepet profesjon over to sider. Som lege finner jeg det underlig at det ikke refereres til Eliot Freidsons sentrale verk fra 1970 (1) om legeprofesjonen, et arbeid som kom til å danne grunnlaget for bøker av samme forfatter om flere profesjoner og mer generelle perspektiver på profesjonenes rolle i samfunnet. Dette viser seg å være den første av flere observasjoner som trekker i retning av at jeg oppfatter boken som et hastverksarbeid. På side 11 legges det opp til en beskrivelse av forhold i Australia, Canada og England. Når utdypningen kommer, er Canada erstattet med Sverige. Filosofen Åge Wifstad omtales minst to ganger som samfunnsmedisiner. Forfatterne argumenterer for større frimodighet, noe jeg ikke er uenig i, og viser det selv i tekst med nokså ureflekterte ytringer: «Å bli miskjent gir en ubalanse $i$ forholdet mellom mennesker, og det innebærer en krenkelse av individets identitet». Denne bruken av begrepet krenkelse representerer etter mitt skjønn en utvidelse og kan lede til inflasjon. Boken er rikt utstyrt med setninger om hva vi skal få høre om senere, og hva vi alt er blitt fortalt. Den korte teksten kunne altså vært betraktelig kortere.

Det får være nok. Heldigvis var det en del å lære hist og her, og det skulle bare mangle fra et akademisk forlag. Litteraturlisten er av verdi. Men kapitlet om formålet var uklart, målgruppen var uklar, argumentasjonen var uklar og konklusjonen uklar. Derfor kan jeg ikke anbefale den, og det er jeg oppriktig lei meg for. En tekst som kunne ha ansporet leger til å ta inn over seg hvor viktig anerkjennelse er, ville vært gull verdt.

\section{Pål Gulbrandsen}

Helse Øst kompetansesenter

for helsetjenesteforskning

Akershus universitetssykehus

Litteratur
1. Freidson E. Profession of Medicine: : A Study of the Sociology of Applied Knowledge. New York, NY Harper and Row, 1970

\section{En perle av en studie}

Schjønsby HP.

Sundhedscollegiet 1809-1815

Det første sentrale administrasjons- og tilsynsorgan for helsevesenet i Norge. 82 s, tab, ill. Oslo: Helsetilsynet, 2009. Pris gratis ISSN 1503-4798 lelektronisk utgave: www.helsetilsynet.no)

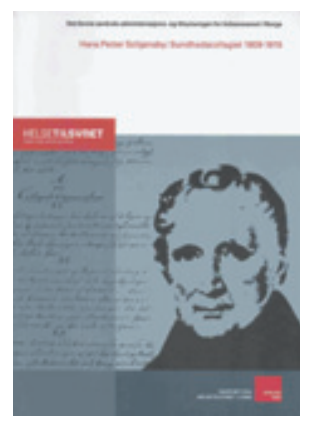

Opprettelsen av faglig kompetente organer for rådgivning i medisinske spørsmål var langt fra noe nytt innenfor mer eller mindre eneveldige statsforvaltninger i tidligmoderne tid. Slik sett kan man se

Sunnhetskollegiet som en videreføring av praksis fra 1700-tallet (enkelte steder litt før): altså det som er kalt det opplyste eneveldet, eller det opinionsstyrte eneveldet. Et stykke på vei fungerte Sunnhetskollegiet også som en form for legitimering av kongedømmets beslutninger.

Sunnhetskollegiet i Christiania var kanskje først og fremst en kriseløsning, opprettet i 1809 som en administrativ tilpasning til utenrikspolitiske forhold som ikke hadde vært mer alvorlige siden midt på 1600-tallet. Slik sett delte Sunnhetskollegiet et stykke på vei skjebne med staten Norge - som vrakgods eller krigsbytte i en stormaktskonflikt.

Like fullt bør vi merke oss at dansk-norske myndigheter faktisk prioriterte å etablere et organ for helse i periferien Norge, $i$ en situasjon da fastlandssperringene truet kommunikasjonene mellom statsdelene. At helsetilstanden i riket ble oppfattet som vesentlig av staten - på linje med kreditt til næringslivet og kornforsyning - tilsier at Sunnhetskollegiet fortjener en biografi, på tross av sin korte virketid (1809-15). Det er det den tidligere fylkeslegen i Hedmark, Hans Petter Schjønsby, nå har påtatt seg på oppdrag fra Helsetilsynet - og som han har gjort på en glimrende måte.

Blant landets mange historieinteresserte leger er Schjønsby en av dem som forstår å ta historiefaget på alvor på en kompetent, ryddig og forsiktig måte. Det beste i dette heftet er strengt tatt ikke presentasjonen av Sunnhetskollegiets virksomhet - selv om den i seg selv er uhyre interessant og grundig - men analysene av de samfunnsmessige sammenhengene som institusjonen arbeidet innenfor. Her viser for eksempel Schjønsby innsiktsfullt hvordan den høye mortaliteten i Lom kaster lys over dødelighetens årsaker i kriseårene 1809 og 1813. Her viser han for eksempel også svært interessant hvordan Sunnhetskollegiet taklet folkelig motstand mot koppevaksine i Trondheim i 1810.
Enkelte ganger går kanskje Schjønsby litt langt i en lineær historieoppfatning. Når han antyder at Frederik 6. (1768-1839) i realiteten la grunnlaget for det «helsevesenet vi har i dag», tillegges nok den dansknorske monarken noe overdrevne evner til å forutse fremtiden. Kongen hadde i praksis ikke noe valg og handlet etter beste skjønn. Slike detaljer spiller likevel ingen rolle. Heftet er fullt av gode observasjoner, interessante analyser og fruktbare sammenhenger. Alle leger med den minste flik av interesse for å sette dagens helsesituasjon i perspektiv - og det er vel de fleste - burde ta seg tid til å lese.

Schjønsby forstår svært mye av den tidligmoderne perioden - og forstår å formidle sin innsikt på en entusiastisk måte. Litt synd derfor, at denne lille perlen av en studie fort kan bli anonymt bortglemt blant kjedelige rapporter fra Helsetilsynet. Den hadde fortjent å komme ut i bokform, godt og interessant illustrert som den også er.

Ole Georg Moseng

Institutt for helse og samfunn

Universitetet i Oslo

\section{Omfattende om malariamikroskopi}

Verdens helseorganisasjon Basic Malaria Microscopy

Part I. Learner's guide. 2. utg. 83 s, ill.

Genève: WHO, 2010. Pris CHF 25

ISBN 978-92-4-154782-6

Verdens helseorganisasjon

Basic Malaria Microscopy

Part II. Tutor's guide. 2. utg. 53 s, ill.

Genève: WHO, 2010. Pris CHF 25

ISBN 978-92-4-154791-8

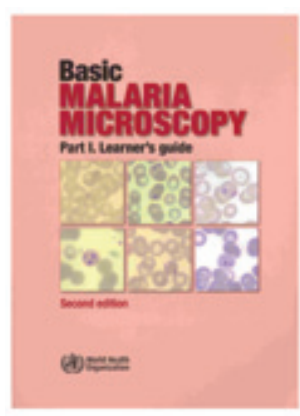

Første utgave av Basic Malaria Microscopy ble utgitt i 1991 og er siden kommet i flere opptrykk. Nå foreligger andre utgave, som er en revidert utgave av den snart 20 år gamle førsteutgaven.

Selv om hurtigtester for malaria i økende grad er blitt aktuelt, vil mikroskopi fortsatt være den diagnostiske metoden som gir mest informasjon. Det forutsetter imidlertid 
at den mikroskopiske diagnostikken er av god kvalitet, hvilket ikke alltid har vært tilfelle. Grundig opplæring av personer som utfører mikroskopi av malariapreparater, er derfor av stor viktighet $i$ alle malariaprogrammer, slik at man kan stole på mikroskopifunnene som rapporteres. Det er bakgrunnen for at man har utarbeidet disse to heftene.

Første hefte, Learner's guide, som er beregnet på studenter som skal lære seg malariamikroskopi, inneholder bl.a. kapitler om mikroskopet, hvordan man lager preparater, og først og fremst om hvordan man undersøker preparatene. Innledningsvis i hvert kapittel blir det presisert hvilke kunnskaper man forventer at kapitlet skal gi studenten. Heftet inneholder en mengde nydelige tegninger av alle stadier av de fire mest utbredte malariaparasittene, slik man kan se parasittene ved mikroskopi av tynne (blodutstryk) og tykke dråper. En CD med mange fine fotografier av malariaparasitter følger med heftet.

Det andre heftet, Tutor's guide, er lærerens veileder. Heftet har mange av de samme kapitteloverskriftene som studentveilederen, men er uten tegningene. Heftet inneholder et eksempel på timeplan for hvordan man kan legge opp et fem ukers kurs i malariamikroskopi. Forslaget virker systematisk og grundig gjennomtenkt og er sikkert basert på erfaringer fra gjennomførte kurs.

De to heftene tar sikte på å være hjelpemidler for studenter og lærere på kurs for laboratorieteknikere eller bioingeniører som skal lære grundig mikroskopi av malariapreparater. Heftene er derfor mest egnet for kurs i malariaendemiske områder. Kurs av et slikt omfang som heftene legger opp til, arrangeres ikke i Norge, og det er derfor lite aktuelt å bruke heftene som kurslitteratur her til lands. Heftene, særlig Learner's guide, kan imidlertid være egnet til selvstudium, både for lærere som underviser på kurs i parasittologi, og for bioingeniører og leger som vil tilegne seg grundige kunnskaper i malariamikroskopi. I alle sammenhenger bør veilederen helst brukes sammen med WHO Bench Aids for Malaria Microscopy.

\section{Bjørn Myrvang}

Kompetansesenter for importog tropesykdommer

Oslo universitetssykehus, Ullevål

\section{Nytt liv med riktig mat}

Hexeberg S

\section{Frisk med lavkarbo}

Nytt liv med riktig mat. 236 s, tab, ill. Oslo: Cappelen Damm, 2010. Pris NOK 329

ISBN 978-82-02-32273-1

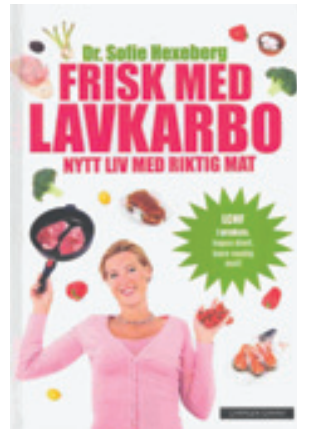

Frisk med lavkarbo er en casebasert slankebok. Målgruppen er mennesker som sliter med overvekt og sykdom. Språket er enkelt, lettlest og forklarende, men det kan likevel være en utfordring for folk uten helsefaglig og/eller akademisk bakgrunn å forstå alt. Lege Sofie Hexeberg skriver engasjert og personlig om sitt syn på kosthold og helse. Hun mener at det optimale kostholdet er et jeger- og samlerkosthold som mennesker har levd av og utviklet seg på i flere millioner år. Hun skriver: «Jeg har kommet til den erkjennelsen at det er for mye karbohydrater og ikke fett som er hovedårsaken til mange av livsstilssykdommene våre. Et karbohydratfattig kosthold er veien å gå for de aller fleste som sliter med overvekt og insulinresistens». Hun er uenig i kostholdsrådene fra Ernæringsrådet og Diabetesforbundet og mener at rådene fører til at mange i Norge blir overvektige og syke. Videre forklarer hun at hun ikke dokumenterer sine råd gjennom forskning fordi det er for dyrt og tidkrevende, og hun ønsker å bruke sin tid og kompetanse på pasienter som trenger hjelp nå. I denne boken omtaler hun 34 pasientkasus. Forfatteren hevder at lavkarbokosthold har hjulpet disse pasientene med overvekt, fedme, hypertensjon, diabetes, spiseforstyrrelser, hypotyreose, sarkoidose, fibromyalgi, artrose, psoriasisartritt, Bekhterevs sykdom, tannkjøttbetennelse, $\mathrm{ME}, \mathrm{PCO}$, infertilitet, menopause, migrene og atrieflimmer. Hun supplerer pasienthistoriene med tabeller med laboratoriesvar før og etter omlegging av kostholdet, og hun omtaler de aktuelle sykdommene og blodprøvesvarene fortløpende etter hver pasienthistorie. Forfatteren avslutter med et oppskriftskapittel, ordforklaringer og en oversikt over karbohydrater i diverse matvarer. Det er også henvisninger til aktuell litteratur og Internett-sider.

Overvekt er blitt en folkesykdom, og pilen peker stadig oppover. Kan Hexeberg klare å snu trenden? Hun har tatt utfordringen. Det finnes dessverre ingen god dokumentasjon over eventuelle ulemper eller risikoer med lavkarbodietten, noe som gjør det problematisk å skulle anbefale den til pasienter. Men det spiller kanskje ingen rolle, pasientene har allerede funnet den.
Hexebergs bok lå på «10 på topp»-listen forrige gang jeg var innom bokhandelen.

Maja Husa

Legene på Sinsen

Oslo

\section{Lovisenbergs historie}

Kaltenborn A-C, Holm B, Larsen IF, red.

\section{Pionérer for pasienten}

Lovisenberg diakonale sykehus: et tverrsnitt av historien. 288 s, ill. Oslo: Forlaget Snorre, 2009 ISBN 978-82-8125-017-8

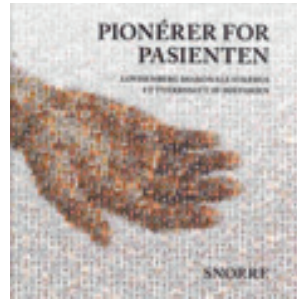

Opprettelsen av Diakonisse-Anstalten i Christiania i 1868 blir ofte sett på som begynnelsen på den moderne sykepleien i Norge. At navnet nettopp var Diakonisse-

Anstalten avspeilet tydelig det primære siktemålet: Det skulle først og fremst være en utdanningsinstitusjon, dernest et sykehus. Navnet på anstalten er i grunnen et kapittel for seg, endringene har vært mange gjennom årene. Det var først i 1993 at den fikk dagens navn: Lovisenberg Diakonale Sykehus.

Nå har en gruppe ildsjeler skrevet historien om sykehuset. Det er blitt en lekker bok med stive permer, blankt papir og mange illustrasjoner. De 140 årene er delt inn i fire tidsbolker: 1868-1929: Pionértid preget av diakonissene; 1929-49: Overgangstid og krig; 1949-93: Modernisering og profesjonalisering; 1993-2008: Et nytt sykehus med lang tradisjon. Hver bolk avsluttes med en oppsummering. I tillegg er det hele 257 noter og referanser. Ikke alle er like informative. Vi får vite at Norges første røntgenapparat ble innkjøpt ved Diakonisseanstaltens sykehus allerede i 1897 , bare to år etter oppdagelsen av røntgenstrålene. Det var overlege Unger Vetlesen (1851-1914) som sendte reservelege Christian Sontum (1858-1902) til Tyskland for å lære om dette nye, og han kjøpte med seg et apparat hjem til sykehuset. Rikshospitalet fikk røntgenapparat først ett år senere, så pasientene ble kjørt fra Rikshospitalet til Diakonisseanstaltens sykehus for å ta bilder det første året. Dette apparatet var visstnok i bruk til begynnelsen av 1920-årene. Opplysningen om Sontums reise er belagt med note 34, som opplyser: «Haugen K. Personlig kommunikasjon» uten at leserne blir særlig klokere av det.

Nærmere 60 personer har vært involvert i utgivelsen. Redaksjonskomiteen har bestått av Anne-Cecilie Kaltenborn og legene Bjørn Holm og Ingegerd Frøyshov Larsen. I tillegg navngis tre konsulenter og 